\title{
PROSPEK PENGEMBANGAN USAHATANI CABAI MERAH (Capsicum annuum L.) DI DESA SUKALAKSANA KECAMATAN BANYURESMI JAWA BARAT
}

\author{
Kuswarini Kusno ${ }^{1}$, Sauma Hanuuf ${ }^{2}$, Pandi Pardian ${ }^{1}$, Eti Suminartika ${ }^{1}$ \\ ${ }^{1}$ Departemen Sosial Ekonomi Pertanian Fakultas Pertanian Universitas Padjadjaran \\ ${ }^{2}$ Alumni Program Studi Agribisnis, Fakultas Pertanian, Universitas Padjadjaran
}

\begin{abstract}
Abstrak
Produktivitas cabai merah yang rendah menandakan terdapat masalah cukup serius pada aspek budidayanya. Perubahan iklim yang ekstrim juga menyebabkan tanaman cabai merah mengalami kerusakan. Akibatnya, produksi menurun sehingga harga produksi meningkat dan pendapatan petani menurun. Penelitian ini dilakukan untuk mengetahui keragaan usahatani cabai merah dan menganalisis pendapatan petaninya. Desain penelitian adalah metode kuantitatif dengan teknik survey terhadap 77 responden yang ditarik secara simple random sampling. Data dianalisis menggunakan distribusi frekuensi dan analisis pendapatan serta rasio Revenue Cost (RC). Hasil penelitian menunjukkan mayoritas petani di Desa Sukalaksana adalah petani gurem (berlahan sempit) yang berstatus pemilik. Ratarata luas lahan garapan adalah 0,32 hektar. Budidaya cabai merah yang dilakukan petani berlahan sempit, sedang maupun luas melalui tahapan kegiatan yang sama dan menggunakan alat-alat pertanian yang sederhana. Tenaga kerja yang digunakan adalah buruh tani. Cabai dijual ke bandar dalam keadaan masih berwarna hijau dengan harga yang berfluktuasi setiap bulannya. Pendapatan petani berlahan sempit, sedang, dan luas per hektar per musim tanam masing-masing adalah $\mathrm{Rp} 15.750 .817, \mathrm{Rp} 43.092 .359$, Rp 49.091.756. Dengan demikian, semakin tinggi luas lahan semakin tinggi tingkat pendapatan. Berdasarkan analisis rasio RC, usahatani di semua kategori luas lahan adalah menguntungkan. Nilai R/C tertinggi dicapai oleh usahatani di lahan sedang yakni 2,4.
\end{abstract}

Kata kunci: cabai merah, keragaan, usahatani, analisis pendapatan

\begin{abstract}
The low productivity of red chili indicates that there is a serious problem in the cultivation aspect. In addition, extreme climate change also causes red chili plants to be damaged. As a result, production decreases so that the price of production increases and farmers income decreases. This research was conducted to determine the performance of red chilli farming and analyze farmers' income. The research design was a quantitative method with a survey technique of 77 respondents drawn by simple random sampling. Data were analyzed using frequency distribution, income analysis and Revenue Cost (RC) ratios. The results showed the majority of farmers in Sukalaksana Village were smallholders (narrow land) who were the owners. The average area of land under cultivation was 0.32 hectares. Red chilli cultivation was carried out by farmers with narrow, medium and wide land through the same stages of activity using traditional tools. The labor used was laborers. Chili was sold to the wholesaler ("bandar") in green conditions with prices that fluctuate each month. The income of farmers who have narrow, medium and wide land per hectare per planting season was $R p$. 15,750,817, Rp. 43,092,359, Rp. 49,091,756, respectively. So, the higher the area of land, the higher the level of farmer income. Based on the RC ratio, farming in all of categories of land area is profitable. The highest $R / C$ value was achieved by farming on medium land, which is 2.4 .
\end{abstract}

Keywords: red chili, performance, farming, income analysis 


\section{Pendahuluan}

Produksi sayuran di Indonesia dari tahun ke tahun cenderung meningkat (Statistik Pertanian, 2017). Ada 2 macam sayuran yang dibudidayakan di Indonesia yaitu tanaman semusim dan tahunan. Jawa Barat merupakan salah satu provinsi penghasil tanaman sayuran semusim. Di Jawa Barat, tanaman sayuran semusim yang memiliki produksi tinggi adalah tomat, kubis, kentang, cabai merah dan petsai (BPS, 2018). Peningkatan luas panen yang paling signifikan di Jawa Barat adalah pada komoditas cabai merah senilai $32,38 \%$, (dari 16.315 ha pada tahun 2016 menjadi 21.598 ha pada tahun 2017) (BPS, 2018).

Cabai merah (Capsicum annuum L.) merupakan komoditas sayuran yang memiliki nilai ekonomis cukup tinggi. Kebutuhan cabai terus meningkat setiap tahun sejalan dengan meningkatnya jumlah penduduk dan berkembangnya industri yang membutuhkan bahan baku cabai. Cabai yang rasanya pedas dan aromanya khas ini, mengandung banyak nutrisi yang bermanfaat bagi kesehatan tubuh. Nutrisi yang terkandung dalam cabai merah adalah protein, lemak, karbohidrat, kalsium serta vitamin A, B1, dan C (Piay, et al., 2010). Selain itu, cabai merah mengandung zat mucokinetik yaitu zat yang mampu mengatur, mengurangi, atau mengeluarkan lendir dari paru-paru (Prajnata, 2011).

Harga cabai merah sangat fluktuatif. Berdasarkan data portal informasi harga pangan

(http://priangan.org/dashboard/umum/2)

sebagai platform sumber referensi dari data Dinas Pertanian Provinsi Jawa Barat, dapat diketahui bahwa harga eceran cabai merah di Provinsi Jawa Barat mengalami fluktuasi pada tahun 2018 setiap bulannya. Harga tertinggi terjadi pada bulan Februari 2018 yang mencapai $\mathrm{Rp} 47.042 / \mathrm{kg}$ dan harga terendah terjadi pada bulan September 2018 yang mencapai Rp $26.545 / \mathrm{kg}_{\text {. Harga yang }}$ berfluktuasi ini dapat menyebabkan petani mengalami kesulitan dalam menjaga kesinambungan produksinya akibat kekurangan modal.

Menurut Piay, et al., (2010), salah satu sentra produksi utama cabai merah di Jawa Barat adalah Kabupaten Garut. Kontribusi produksinya senilai $33,35 \%$ pada tahun 2016 (BPS, 2018). Salah satu sentra cabai merah di Kabupaten Garut adalah Kecamatan Banyuresmi. Pada tahun 2017, produksi cabai merah Kecamatan Banyuresmi menempati urutan ketiga terbesar setelah Kecamatan Cisurupan dan Kecamatan Sucinaraja (BPS Kabupaten Garut, 2018). Desa Sukalaksana merupakan salah satu desa di Kecamatan Banyuresmi yang petaninya melakukan usahatani cabai merah sebagai mata pencaharian utama (Profil Desa Sukalaksana, 2015). Tetapi, produktivitas cabai merah di Desa Sukalaksana paling rendah dibandingkan dengan enam desa lainnya (Tabel 1).

Tabel 1.

Produktivitas cabai merah di Kecamatan Banyuresmi tahun 2014

\begin{tabular}{|c|c|c|c|c|}
\hline No. & Desa & $\begin{array}{c}\text { Produksi } \\
\text { (ton) }\end{array}$ & $\begin{array}{c}\text { Luas } \\
\text { Panen } \\
\text { (ha) }\end{array}$ & $\begin{array}{c}\text { Produk } \\
\text {-tivitas } \\
\text { (ton/ha) }\end{array}$ \\
\hline 1. & Sukaraja & 5.000 & 215 & 23,2 \\
\hline 2. & Sukakarya & 6.232 & 229 & 27,2 \\
\hline 3. & Pamekarsari & 5.970 & 225 & 26,5 \\
\hline 4. & Sukasenang & 3.000 & 115 & 26,08 \\
\hline 5. & Dangdeur & 3.100 & 112 & 27,7 \\
\hline 6. & Karyasari & 700 & 35 & 20 \\
\hline 7. & Sukalaksana & 2.100 & 110 & 19 \\
\hline & Jumlah & 20.729 & 1040 & 169,68 \\
\hline & Rata-rata & $2.961,3$ & 148,7 & 24,2 \\
\hline
\end{tabular}

Sumber: Kecamatan Banyuresmi dalam Angka, 2016.

Produktivitas cabai merah yang rendah disebabkan ada masalah cukup serius dalam budidayanya (Piay, et al., 2010). Budi daya cabai memang berisiko tinggi. Namun, resiko ini bisa diminimalisir dengan memperhatikan syarat tumbuhnya. Syarat pertama adalah memperhatikan curah hujan 
dan kelembaban, yang kedua adalah jenis tanah, pH tanah dan jenis lahan (https://agromedia.net/mengenal-syarattumbuh-cabai-2/). Tanaman cabai merah juga akan mengalami kerusakan akibat perubahan iklim yang ekstrim. Akibatnya terjadi penurunan produksi sehingga harga produksi naik. Akibat selanjutnya adalah tingkat pendapatan petani menurun.

Berdasarkan berbagai uraian di atas, penelitian ini dilakukan untuk mengetahui keragaan usahatani cabai merah dan menganalisis tingkat pendapatan petaninya.

\section{Metode Penelitian}

Penelitian ini dilakukan pada tahun 2019 di Desa Sukalaksana Kecamatan Banyuresmi Kabupaten Garut, Provinsi Jawa Barat. Desain penelitian yang digunakan adalah metode kuantitatif dengan teknik survey. Metode kuantitatif terdiri dari proses pengumpulan, analisis, interpretasi, dan penulisan hasil penelitian (Creswell, 2014).

Variabel yang diamati untuk menggambarkan keragaan usahatani cabai merah adalah:

- persiapan lahan yang meliputi jenis lahan dan penglolahannya.

- Penggunaan benih: varietas benis dan persemaiannya,

- Penanaman: waktu, cara, dan pola tanam

- Pemeliharaan: penyiangan, penyiraman, pemupukan susulan, penyulaman, pemasangan ajir,

- Pupuk: jenis dan dosis pupuk, serta waktu pemupukan,

- Irigasi: Jenis irigasi dan sumber air

- Jenis OPT dan cara pengendaliannya

- Panen: waktu, intensitas, dan cara panen,

- Pasca panen: sortasi, pengangkutan, penyimpanan, pengemasan.

Untuk menentukan pendapatan bersih petani digunakan variabel-variabel berikut:

- Biaya tetap: sewa lahan, penyusutan alat dan mesin.

- Biaya variabel: biaya benih, pupuk, pestisida, tenaga kerja, dan biaya ajir.
Dalam penelitian ini, sampel petani responden dipilih secara acak dengan teknik simple random sampling. Banyaknya responden diperoleh dengan menggunakan rumus Slovin sebagai berikut:

$$
\mathrm{n}=\frac{\mathrm{N}}{1+\mathrm{N} e^{2}}
$$

$\mathrm{n}$ adalah ukuran sampel, $\mathrm{N}$ adalah ukuran populasi $=337$ dan e adalah tingkat kesalahan yang ditetapkan sebesar 0,1 . Dengan demikian, $\mathrm{n}=77$ orang. Pemilihan ke 77 responden secara acak dilakukan dengan bantuan program aplikasi SPSS.

Data terdiri dari data primer dan sekunder. Data primer diperoleh dengan mengunjungi lokasi penelitian untuk mewawancarai petani dengan kuesioner. Sedangkan data sekunder berasal dari institusi terkait, literatur dan studi sebelumnya yang diperoleh baik secara offline maupun online.

Data dianalisis menggunakan distribusi frekuensi untuk mengetahui keragaan usahatani cabai merah, dan menggunakan analisis pendapatan serta rasio RC untuk mengetahui prospek usahatani cabai merah. Tahapan analisisnya adalah sebagai berikut:

1. Membangun tabel distribusi frekuensi untuk mendeskripsikan proses budidaya cabai merah.

2. Menghitung penerimaan petani dengan rumus di bawah ini: (Suratiyah, 2015)

dimana:

$$
\mathrm{TR}=\mathrm{P} \times \mathrm{Q}
$$

$\mathrm{TR}=$ Total penerimaan $(\mathrm{Rp} /$ musim tanam/tahun)

$\mathrm{Q}=$ Kuantitas $(\mathrm{kg} /$ musim tanam $/$ tahun

$\mathrm{P}=$ Harga / satuan produk $(\mathrm{Rp} / \mathrm{kg} /$ musim tanam/tahun.

3. Menghitung pendapatan petani sebagai berikut: (Suratiyah, 2015)

$$
\begin{aligned}
& \pi=\mathrm{TR}-\mathrm{TC} \\
& \mathrm{TC}=\mathrm{FC}+\mathrm{VC}
\end{aligned}
$$

dimana:

$\pi=$ Pendapatan $/$ musim tanam $/$ tahun $\mathrm{TC}=$ Biaya total $/$ musim tanam $/$ tahun $\mathrm{FC}=$ Biaya tetap $(\mathrm{Rp})$ 
$\mathrm{VC}=$ Biaya variabel (Rp).

4. Menghitung rasio RC: (Soekartawi, 2016)

$$
\mathrm{R} / \mathrm{C}=\mathrm{TR} / \mathrm{TC}
$$

\section{Hasil dan Pembahasan}

\section{Keadaan umum Desa Sukalaksana}

Luas wilayah Desa Sukalaksana adalah 280 Ha dengan topografi yang bervariasi. Bagian timur merupakan daerah perbukitan yang memanjang dari barat ke timur sedangkan wilayah utara adalah persawahan. Terletak pada ketinggian 700 mdpl, desa ini memiliki iklim tropis dengan suhu rata-rata 25-30 derajat Celcius.

Penggunaan wilayah yang paling besar adalah untuk perkebunan cabai merah yang mencapai $50 \%$ dari total wilayah. Perkebunan tersebut merupakan perkebunan di lahan kering. Area perkebunan yang luas tersebut menunjukkan Desa Sukalaksana memiliki potensi untuk pengembangan budidaya cabai merah. Petani di Desa Sukalaksana mencapai $44,5 \%$ dan buruh tani mencapai $26,02 \%$ dari total penduduk yang bekerja. Penduduknya memilih bekerja dalam sektor pertanian karena potensi sektor pertanian yang besar.

\section{Keragaan usahatani cabai merah}

Menurut Sastraatmaja (2010), petani di Indonesia dapat digolongkan menjadi petani besar (memiliki lahan lebih dari $1 \mathrm{ha}$ ), petani kecil (memiliki lahan antara 0,5-I ha), dan petani gurem (memiliki lahan kurang dari $0,5 \mathrm{ha}$ ). Sebaran petani responden cabai merah di Desa Sukalaksana adalah sebagai berikut: 1 orang $(1,3 \%)$ petani besar, 8 orang $(10,4 \%)$ petani kecil, dan 68 orang $(88,3 \%)$ petani gurem. Dengan demikian, mayoritas petani responden adalah petani gurem.

Kisaran luas lahan yang digarap petani responden adalah $0,1-1,75$ hektar dengan rata-rata seluas 0,32 hektar Berdasarkan status penguasaan lahan, 45 responden (58\%) adalah pemilik dan 32 responden (42\%) adalah penyewa lahan.. Menurut
Suratiyah (2015), hubungan tanah dan manusia terbagi dalam tiga tingkat dari yang terkuat sampai yang terlemah yaitu hak milik, hak sewa dan hak bagi hasil (sakap). Perbedaan hubungan tersebut akan berpengaruh pada kesediaan petani dalam meningkatkan produksi, memperbaiki kesuburan tanah dan intensifikasi.

\section{a) Pengolahan tanah}

Semua petani responden melakukan pengolahan tanah dalam 4 tahap. Tahap pertama yaitu pembersihan dan pembalikan tanah. Lahan dibersihkan terlebih dahulu dari sisa-sisa tanaman sebelumnya, plastik mulsa, dan sampah lainnya. Tanah kemudian dibajak menggunakan cangkul. Semua petani menggunakan cangkul, bukan traktor, karena rata-rata luas garapan $<0,5$ ha. Kedalaman tanah antara 20 hingga 30 $\mathrm{cm}$. Hal ini dilakukan agar akar tanaman dapat dengan leluasa memperoleh zat hara yang ada di dalam tanah. Setiap petani hanya memiliki 1 cangkul karena petani mengandalkan tenaga kerja luar keluarga atau buruh tani yang membawa cangkul pribadi.

Tahap kedua yaitu pembuatan bedengan. Bedengan dibuat dengan ketinggian $30 \mathrm{~cm}$ hingga $40 \mathrm{~cm}$, dengan lebar sekitar $100 \mathrm{~cm}$, dan jarak antar bedengan $40 \mathrm{~cm}$ hingga 50 $\mathrm{cm}$. Panjang bedengan disesuaikan dengan bentuk lahannya, agar bedengan dapat dilewati oleh petani serta memudahkan pematokan lahan di masa yang akan datang.

Tahap ketiga yaitu pemupukan dasar yang dilakukan sebelum penanaman dengan memberikan pupuk kandang yaitu kotoran ayam. Dosis rata-rata adalah $159 \mathrm{~kg}$ untuk lahan seluas $0-0,5$ ha, $312,5 \mathrm{~kg}$ untuk 0,5 $<1$ ha, dan $1000 \mathrm{~kg}$ untuk lahan seluas $>1$ ha. Tanah bedengan diaduk secara merata dan dibiarkan selama 2 minggu.

Tahap keempat yaitu pemulsaan. Umumnya pemulsaan dilakukan untuk menghindari gangguan gulma, hama penyakit, tercucinya pupuk oleh air hujan serta menjaga suhu tanah dan kelembabannya agar relatif stabil. Mulsa yang digunakan adalah mulsa plastik 
hitam perak. Mulsa lalu dilubangi dengan jarak sesuai yang diinginkan dan berpola sejajar.

\section{b) Penggunaan bibit}

Semua responden menggunakan bibit hasil penyemaian benih varietas Viktor. Benih disemai di polybag yang diisi dengan media tanam berupa campuran tanah dan pupuk kandang dengan perbandingan 3:1. Masingmasing polybag diisi 1-2 butir benih cabai merah, kemudian disusun rapi diatas bedengan. Bedengan diberi naungan setinggi 1 meter agar polybag benih terlindung dari terpaan sinar matahari langsung atau air hujan. Benih varietas Viktor merupakan benih unggul yang dapat menghasilkan cabai segar \pm 14 ton/ha (Keputusan Mentri Pertanian, 2006).

Setelah berumur 1-2 minggu, bibit mulai bertunas. Pada umur 2 minggu naungan bedengan dipindahkan agar bibit menerima cahaya matahari lebih banyak. Setelah 3 minggu, bibit siap dipindahkan ke lahan untuk ditanam. Rata-rata penggunaan benih dapat dilihat pada Tabel 2.

\section{Tabel 2}

Penggunaan benih per luas kepemilikan lahan

\begin{tabular}{lcccc}
\hline $\begin{array}{l}\text { Luas } \\
\text { (ha) }\end{array}$ & Kategori & $\begin{array}{c}\text { Benih } \\
\text { (pak) }\end{array}$ & frek & $\%$ \\
\hline $0,1-<0,5$ & Sempit & 3 & 68 & 88,3 \\
$0,5-1$ & Sedang & 6 & 8 & 10,4 \\
$>1$ & Luas & 12 & 1 & 1,3 \\
Jumlah & & & 77 & 100
\end{tabular}

Sumber: Data primer diolah (2019)

\section{c) Penanaman bibit}

Bibit diletakkan di tengah lubang tanam kemudian ditimbun media tanam hingga padat, agar akar tanaman kokoh dan tanaman tidak mudah goyah. Penanaman dilakukan saat bulan basah. Pemilihan waktu tanam yang tepat sangatlah penting, karena berhubungan dengan ketersediaan air, curah hujan, temperatur dan tanda maupun gejala datangnya hama/penyakit. Mayoritas petani (70\%) melakukan penanaman pada bulan Desember. petani lainnya (30\%) menanam di bulan Januari karena mengincar harga tinggi ketika masa Idul Fitri tiba. Semua petani melakukan penanaman pada pagi hari antara pukul 07.00-09.00 WIB atau sore hari setelah pukul 15.00 WIB. Setelah penanaman, dilakukan penyemprotan awal untuk menghindari hama penyakit.

\section{d) Pemeliharaan}

Pada tahapan pemeliharaan diperlukan banyak waktu untuk pengawasan agar tanaman tetap dalam kondisi optimal untuk tumbuh. Pemeliharaan terdiri dari: penyulaman, penyiraman, pemasangan ajir, pemupukan tambahan, dan pengendalian hama penyakit.

Penyulaman dilakukan setelah 1 - 2 minggu penanaman. Penyulaman dilakukan untuk mengganti tanaman utama yang mati dengan bibit yang tersisa pada saat penyemaian.

Semua petani memanfaatkan air hujan sebagai media penyiraman. Penyiraman manual hanya dilakukan ketika tanah sudah terlalu kering. Caranya dengan menggunakan air hujan yang ditampung didalam balongan yang dibuat oleh petani.

Pemasangan ajir dilakukan ketika tanaman telah berumur sekitar 4 minggu. Pemasangan ajir menggunakan sistem pengajiran miring, yaitu menancapkan dua bilah bambu secara menyilang sejajar pada percabangan tanaman searah panjang bedengan. Pemasangan ajir ini dilakukan dengan menyelang satu tanaman. Kemudian ajir dihubungkan dengan ajir lainnya menggunakan tali rafia.

\section{e) Pemupukan}

Pemupukan tambahan dilakukan 2 - 3 minggu setelah penanaman dan dilakukan secara rutin setiap 2 minggu sekali. Tujuan pemupukan tambahan adalah untuk memenuhi nutrisi dan hara tanaman, agar tidak terjadi kompetisi unsur hara antar 
tanaman. Pemupukan tambahan ini dilakukan dengan menggunakan teknik pengkocoran yaitu melarutkan campuran pupuk dan air dengan konsentrasi tertentu (sesuai kebutuhan tanaman) kemudian larutan tersebut dialirkan ke setiap lubang tanam. Teknik pengkocoran dilakukan agar tanah yang telah tertutup mulsa plastik mudah menyerap nutrisi dari pupuk. Semua petani responden menggunakan beberapa jenis pupuk. Masing-masing pupuk rata-rata penggunaannya adalah sebagai berikut: 315 $\mathrm{kg} / \mathrm{ha}$ NPK, $118 \mathrm{~kg} / \mathrm{ha}$ ZA, $83 \mathrm{~kg} / \mathrm{ha}$ TSP, 43 $\mathrm{kg} / \mathrm{ha} \mathrm{KNO}_{3}, 12 \mathrm{~kg} / \mathrm{ha} \mathrm{KCL}$, dan $12 \mathrm{~kg} / \mathrm{ha}$ Grower. Jadi, pupuk NPK yang paling banyak digunakan oleh petani responden. Pupuk NPK adalah pupuk penyubur tanah yang mengandung unsur hara utama nitrogen, fosfor dan kalium. Pupuk NPK juga merupakan pupuk majemuk yang paling umum digunakan.

\section{f) Pengendalian OPT}

Organisme Penggangu Tanaman (OPT) yang menyerang tanaman cabai merah adalah hama ulat dan lalat buah sedangkan penyakit yang menyerang adalah antraknosa, busuk daun dan busuk batang. Pengendalian OPT dilakukan secara rutin dua minggu sekali menggunakan pestisida (insektisida) kimia. Namun jika serangan hama dan penyakit sedang tinggi, penggunaan pestisida ditingkatkan menjadi $1-3$ kali per minggu.

Serangan hama yang terjadi meliputi serangan ulat yang dialami oleh 20 responden $(26 \%)$, serangan lalat buah dialami oleh 17 responden (22\%), serta serangan ulat dan lalat buah dialami oleh 40 orang responden $(52 \%)$. Sedangkan sebaran serangan penyakit adalah sebagai berikut: $66 \%$ petani menghadapi serangan penyakit antraknosa pada tanaman cabai merahnya, $16 \%$ petani mengahadapi antraknosa dan busuk batang, $13 \%$ petani menghadapai antraknosa dan busuk daun, serta 5\% petani menghadapi antraknosa, busuk batang dan busuk daun.

Untuk menghadapi serangan hama dan penyakit, petani menggunakan beberapa jenis pestisida yaitu Demolish, Abacel, Culacron, Bionik dan Amistartop. Rata-rata penggunaan pestisida per hektar masingmasing adalah 2, 2,5, 5,5, 2 dan 4 botol. Pestisida Culacron merupakan insektisida yang dapat membunuh hama ulat dan lalat buah, yang mana kedua hama tersebut paling banyak menyerang tanaman cabai petani responden. Sedangkan fungisida Amistartop digunakan untuk mencegah penyakit tanaman cabai merah.

\section{g) Panen}

Pemanenan dilakukan setelah tanaman berumur 90-100 hari sejak ditanam di bedengan. Cabai dipanen dalam kondisi berwarna hijau karena petani cenderung ingin lebih cepat menjualnya akibat kebutuhan ekonomi. Petani telah memiliki pasar tetap yang bersedia membeli cabai hijau. Cabai dapat dipanen 6-14 kali, tergantung pemeliharaan dan kondisi lingkungan. Cabai dipetik dan dikumpulkan di saung untuk disortasi dan kemudian dimasukkan ke karung. Biasanya setiap karung berisi $40-50 \mathrm{~kg}$ cabai. Dalam satu musim tanam, mayoritas petani $(93,5 \%)$ memanen cabai 13 kali (Tabel 3). Hasil ini dapat menunjukkan bahwa pemeliharaan dan kondisi lingkungan tempat cabai ditanam cukup baik.

\section{Tabel 3}

Frekuensi panen per satu musim tanam

\begin{tabular}{ccc}
$\begin{array}{c}\text { Panen } \\
\text { (kali) }\end{array}$ & Frekuensi & $\%$ \\
\hline 5 & 1 & 1,3 \\
12 & 1 & 1,3 \\
13 & 72 & 93,5 \\
14 & 3 & 3,9 \\
& 77 & 100
\end{tabular}

Sumber: Data primer diolah (2019)

f) Pasca panen 
Petani menjual cabai dalam bentuk segar sehingga tidak ada proses pengolahan dan tidak banyak melalui proses penanganan pasca panen. Cabai yang sudah dipanen dan dimasukan ke karung langsung diantarkan ke rumah bandar atau dijual sendiri ke pasar. Mayoritas petani responden (99\%) menjual cabainya kepada bandar dan 1 responden (1\%) menjual langsung ke pasar. Saluran pasar yang dimiliki bandar yaitu pasar Cikupa di Tangerang, Pasar Cibitung di Bekasi, dan Pasar Kemang di Bogor. Karung-karung cabai yang telah ditimbang langsung dikirim ke pasar tujuan dengan menggunakan truk. Cabai paling banyak dikirim ke pasar Cikupa yaitu yaitu 50\%, ke pasar Cibitung 30\% dan ke pasar Kemang $20 \%$. Bandar melakukan proses tawar menawar harga dengan pedagang di pasar. Harga yang disepakati bandar dan pedagang bukanlah harga yang diterima petani. Petani menerima harga jual cabai setelah harga pasar tersebut dikurangi biaya transportasi dan keuntungan untuk bandar. Bandar akan membayar hasil panen tersebut setelah cabai terjual. Petani yang menjual sendiri hasil panennya memiliki kebebasan untuk menjual ke pasar yang menawarkan harga tertinggi, 1 orang petani responden menjual hasil panennya ke pasar Cibitung di Bekasi.

\section{Analisis pendapatan usahatani cabai merah}

\section{a. Biaya usahatani}

Biaya usahatani cabai merah terdiri dari biaya tetap dan biaya variabel. Menurut Soekartawi (2016), biaya tetap adalah biaya yang relatif tetap jumlahnya, dan terus dikeluarkan walaupun produksi yang diperoleh banyak atau sedikit, sedangkan biaya variabel adalah biaya yang besar kecilnya dipengaruhi produksi yang diperoleh. Biaya usahatani dengan demikian adalah total biaya tetap dan biaya variabel. Biaya usahatani cabai merah untuk setiap kategori luas lahan disajikan pada Tabel 4, 5, dan Tabel 6.

Biaya sewa lahan bervariasi antara $\mathrm{Rp}$. 10.500.000 - Rp. 14.000.000 per hektar per musim. Biaya tersebut biasanya ditentukan berdasarkan kesepakatan antara pemilik dan penyewa lahan dengan mempertimbangkan luas dan kondisi lahan.

Alat-alat yang digunakan mulai dari pembukaan lahan sampai panen adalah cangkul, kored, parang, tangki semprot, tong, ember dan karung. Umur ekonomis setiap alat diperkirakan 5 tahun.

\section{Tabel 4}

Rata-rata biaya usahatani lahan sempit per hektar per musim tanam

\begin{tabular}{|c|c|c|c|c|}
\hline Jenis biaya & Unit & $\begin{array}{l}\text { Kuan- } \\
\text { titas }\end{array}$ & $\begin{array}{c}\text { Harga/ } \\
\text { unit } \\
\text { (Rp) }\end{array}$ & Total (Rp) \\
\hline \multicolumn{5}{|l|}{ BT } \\
\hline Sewa lahan & & & & 547.059 \\
\hline Penyusutan & & & & 3.631 \\
\hline $\begin{array}{c}\text { Mulsa } \\
\text { BV }\end{array}$ & roll & 2,75 & 530.000 & 1.457 .500 \\
\hline Benih & bks & 3 & 110.000 & 330.000 \\
\hline Polybag & bks & 7 & 6.500 & 45.500 \\
\hline Ajir & btg & 2.864 & 350 & 1.002 .400 \\
\hline P.Kandang & $\mathrm{kg}$ & 159 & 10.000 & 1.590 .000 \\
\hline Npk & $\mathrm{kg}$ & 286 & 14.000 & 4.004 .000 \\
\hline $\mathrm{Za}$ & $\mathrm{kg}$ & 107 & 7.000 & 749.000 \\
\hline Tsp & $\mathrm{kg}$ & 74 & 11.000 & 814.000 \\
\hline Kno & $\mathrm{kg}$ & 37,5 & 24.000 & 900.000 \\
\hline $\mathrm{Kcl}$ & $\mathrm{kg}$ & 9,6 & 12.000 & 115.200 \\
\hline Grower & $\mathrm{kg}$ & 11,8 & 18.000 & 212.400 \\
\hline Demolish & bt & 2 & 80.000 & 160.000 \\
\hline Abacel & bt & 2,5 & 90.000 & 225.000 \\
\hline Culacron & bt & 5,5 & 35.000 & 192.500 \\
\hline Bionik & bt & 2 & 25.000 & 50.000 \\
\hline Amistartop & bt & 3,5 & 200.000 & 700.000 \\
\hline TKD & Hok & & & 2.771 .912 \\
\hline TKL & Hok & & & 1.638 .309 \\
\hline & Tot. & & & 17.508 .411 \\
\hline
\end{tabular}

Keterangan: $\mathrm{BT}=$ biaya total, $\mathrm{BV}=$ biaya variabel, $\mathrm{TKD}=$ tenaga kerja dalam keluarga, $\mathrm{TKL}=$ tenaga kerja luar keluarga

Sumber: Data primer diolah (2019)

Upah buruh tani yaitu Rp 50.000 untuk lakilaki dan $\mathrm{Rp} 35.000$ untuk perempuan. Besaran upah ini cukup tinggi jika dibandingkan dengan desa lain. Kegiatan budidaya cabai merah memerlukan banyak tenaga kerja terutama pada tahap 
pengolahan lahan dan pemeliharaan cabai. Cabai memerlukan pemeliharaan yang intensif agar tanaman sehat dan dapat dipanen hingga berkali-kali. Pemeliharaan tersebut memerlukan banyak tenaga kerja, oleh karena itu tenaga kerja dapat mempengaruhi produksi cabai merah besar.

\section{Tabel 5}

Rata-rata biaya usahatani lahan sedang per hektar per musim tanam

\begin{tabular}{ccccc}
\hline Jenis biaya & Unit & $\begin{array}{c}\text { Kuan- } \\
\text { titas }\end{array}$ & $\begin{array}{c}\text { Harga/ } \\
\text { unit } \\
\text { (Rp) }\end{array}$ & Total (Rp) \\
\hline BT & & & & \\
Sewa lahan & & & & 1.112 .500 \\
Penyusutan & & & & 4.202 .875 \\
Mulsa & roll & 7,375 & 530.000 & 3.908 .750 \\
BV & & & & \\
Benih & bks & 6 & 110.000 & 660.000 \\
Polybag & $\mathrm{bks}$ & 18,25 & 6.500 & 118.625 \\
Ajir & $\mathrm{btg}$ & $7.012,5$ & 350 & 2.454 .375 \\
P.Kandang & $\mathrm{kg}$ & 312,5 & 10.000 & 3.125 .000 \\
Npk & $\mathrm{kg}$ & 475 & 14.000 & 6.650 .000 \\
Za & $\mathrm{kg}$ & 175 & 7.000 & 1.225 .000 \\
Tsp & $\mathrm{kg}$ & 137,5 & 11.000 & 1.512 .500 \\
Kno & $\mathrm{kg}$ & 93,75 & 24.000 & 2.250 .000 \\
Kcl & $\mathrm{kg}$ & 37,5 & 12.000 & 450.000 \\
Grower & $\mathrm{kg}$ & 18,75 & 18.000 & 337.500 \\
Demolish & $\mathrm{bt}$ & 3,25 & 80.000 & 260.000 \\
Abacel & $\mathrm{bt}$ & 1,75 & 90.000 & 157.500 \\
Culacron & $\mathrm{bt}$ & $5 ., 5$ & 35.000 & 201.250 \\
Bionik & $\mathrm{bt}$ & 1,25 & 25.000 & 31.250 \\
Amistartop & $\mathrm{bt}$ & 8,75 & 200.000 & 1.750 .000 \\
TKD & $\mathrm{Hok}$ & & & 2.568 .125 \\
TKL & $\mathrm{Hok}$ & & & 2.909 .375 \\
& $\mathrm{Tot}$. & & & 31.685 .953 \\
\hline
\end{tabular}

Sumber: Data primer diolah (2019)

Jika tenaga kerja melakukan pemeliharaan cabai dengan benar maka penggunaan tenaga kerja dapat meningkatkan produksi cabai, sebaliknya jika pemeliharaan tidak dilakukan dengan benar maka tenaga kerja hanya akan meningkatkan biaya produksi.

Tabel 6

Rata-rata biaya usahatani lahan luas per hektar per musim tanam

\begin{tabular}{|c|c|c|c|c|}
\hline Jenis biaya & Unit & $\begin{array}{c}\text { Kuan- } \\
\text { titas }\end{array}$ & $\begin{array}{c}\text { Harga/ } \\
\text { unit }\end{array}$ & Total (Rp) \\
\hline
\end{tabular}

\begin{tabular}{ccccc}
\hline & & \multicolumn{3}{c}{$(\mathrm{Rp})$} \\
\hline BT & & & & \\
Sewa lahan & & & & 7.600 .000 \\
Penyusutan & & & & 4.244 \\
Mulsa & roll & 11 & 530.000 & 5.830 .000 \\
BV & & & & \\
Benih & bks & 12 & 110.000 & 1.320 .000 \\
Polybag & bks & 29 & 6.500 & 188.500 \\
Ajir & btg & 11.250 & 350 & 3.937 .500 \\
P.Kandang & $\mathrm{kg}$ & 1.000 & 10.000 & 10.000 .000 \\
Npk & $\mathrm{kg}$ & 1.000 & 14.000 & 14.000 .000 \\
Za & $\mathrm{kg}$ & 400 & 7.000 & 2.800 .000 \\
Tsp & $\mathrm{kg}$ & 200 & 11.000 & 2.200 .000 \\
Kno & $\mathrm{kg}$ & 300 & 24.000 & 7.200 .000 \\
Kcl & $\mathrm{kg}$ & 200 & 12.000 & 2.400 .000 \\
Demolish & $\mathrm{bt}$ & 10 & 80.000 & 800.000 \\
Abacel & $\mathrm{bt}$ & 15 & 90.000 & 1.350 .000 \\
Culacron & $\mathrm{bt}$ & 4 & 35.000 & 140.000 \\
Bionik & $\mathrm{bt}$ & 0 & 25.000 & 0 \\
Amistartop & $\mathrm{bt}$ & 15 & 200.000 & 3.000 .000 \\
TKD & $\mathrm{Hok}$ & & & 2.305 .000 \\
TKL & $\mathrm{Hok}$ & & & 5.610 .000 \\
& Tot. & & & 70.685 .244 \\
\hline
\end{tabular}

Sumber: Data primer diolah (2019)

\section{b. Penerimaan usahatani}

Penerimaan merupakan jumlah uang yang diterima petani dari penjualan hasil cabainya kepada bandar dan konsumen akhir. Jumlah penerimaan petani cabai merah pada satu musim tanam bergantung pada hasil produksi dan harga yang ada. Harga cabai mengalami fluktuatif hampir setiap bulan dan harga tertinggi umumnya terjadi pada masa mendekati Idul Fitri. Cabai ini umunya dijual ke bandar dalam kondisi masih berwarna hijau yang harganya berkisar antara $\mathrm{Rp} 3.000$ sampai Rp 6.000 per kilogram. Penerimaan petani untuk setiap luas lahan dapat dilihat pada Tabel 7. Tampak bahwa tingkat penerimaan naik seiring dengan bertambahnya luas lahan.

Tabel 7

Penerimaan usahatani per hektar per musim tanam

\begin{tabular}{cc}
\hline Luas lahan (ha) & Penerimaan $(\mathrm{Rp})$ \\
\hline $0,1-<0,5$ (Sempit) & 33.259 .228
\end{tabular}




$$
\begin{array}{rc}
0,5-1 \text { (Sedang) } & 74.778 .313 \\
>1 \text { (Luas) } & 119.777 .000
\end{array}
$$

Sumber: Data primer diolah (2019)

\section{c. Pendapatan usahatani}

Keberhasilan suatu usahatani dilihat dari pendapatan atau keuntungan yang diperoleh petaninya. Pendapatan petani cabai merah di Desa Sukalaksana dalam satu musim tanam dapat dilihat pada Tabel 9.

\section{Tabel 9}

\section{Pendapatan usahatani per hektar per musim} tanam

\begin{tabular}{cc}
\hline Luas lahan (ha) & Pendapatan (Rp) \\
\hline $0,1-<0,5$ (Sempit) & 15.750 .817 \\
$0,5-1$ (Sedang) & 43.092 .359 \\
$>1$ (Luas) & 49.091 .756 \\
\hline
\end{tabular}

\section{Analisis Rasio RC usahatani}

Analisis $\mathrm{R} / \mathrm{C}$ adalah perbandingan antara jumlah penerimaan dan biaya. Pada lahan sempit penerimaan dari usahatani cabai adalah Rp. 33.259.228, sedangkan total biaya yang dikeluarkan adalah $\mathrm{Rp}$ 17.508.411 maka $\mathrm{R} / \mathrm{C}=1,9$. Artinya, setiap $\mathrm{Rp} 1$ biaya yang dikeluarkan akan memberikan penerimaan $\mathrm{Rp} \mathrm{1,9.} \mathrm{Dengan}$ cara yang sama, dari Tabel 7 dan Tabel 8 diperoleh $\mathrm{R} / \mathrm{C}$ untuk lahan sedang $=2,4$ dan $\mathrm{R} / \mathrm{C}$ lahan luas $=1,7$. Rata-rata $\mathrm{RC}$ lahan sedang lebih tinggi dari pada RC lahan lainnya. Hal ini disebabkan biaya produksi pada lahan sedang lebih rendah daripada biaya produksi di kategori lahan lainnya.

\section{Kesimpulan}

Mayoritas petani di Desa Sukalaksana adalah petani gurem (berlahan sempit) yang berstatus pemilik. Luas lahan berkisar antara 0,1 sampai 1,75 hektar dengan ratarata 0,32 hektar. Tahapan kegiatan budidaya cabai merah yang dilakukan petani berlahan sempit, sedang maupun luas adalah sama. Namun tentu saja terdapat perbedaan dalam jenis dan jumlah faktor-faktor produksi yang digunakan. Semua petani menggunakan bibit unggul varietas Viktor. Pupuk yang paling banyak digunakan adalah NPK. Mayoritas petani menggunakan tenaga kerja buruh tani. Hampir semua petani menjual seluruh hasil produksinya kepada bandar dalam kondisi cabai masih berwarna hijau. Harga jualnya berfluktuasi setiap bulan.

Pendapatan petani cabai merah berlahan sempit dalam satu musim per hektar lebih kecil dari pendapatan petani berlahan sedang dan lebih kecil dari pendapatan petani berlahan luas. Usahatani cabai merah menguntungkan untuk setiap kategori luas lahan. Nilai rasio RC tertinggi dicapai oleh usahatani di lahan sedang.

\section{Daftar Pustaka}

Badan Pusat Statistik. 2018. Produksi Hortikultura Sayuran dan Buah Semusim Provinsi Jawa Barat 2017. Bandung: Badan Pusat Statistik Jawa Barat.

Badan Pusat Statistik. 2018. Kabupaten Garut Dalam Angka 2018. Garut: Badan Pusat Statistik Kabupaten Garut. Melalui

Badan Pusat Statistik. 2018. Kecamatan Banyuresmi Dalam Angka 2018. Garut: Badan Pusat Statistik Kabupaten Garut. Melalui

Creswell, John W. 2014. Research Design Qualitative, Quantitative and Mix method Aproach. SAGE Publications, Inc.

Forum Koordinasi Pengendali Inflasi. 2019. "Fluktuasi Harga Cabe Merah" Portal Informasi Harga Pangan. Melalui $<$ http://priangan.org/dashboard/um $\underline{\mathrm{um} / 2}>$ [15/01/19].

Hidayah, Abdul K. 2014. "Analisis Finansial Usahatani Cabai Merah Skala Petani di Kota Samarinda (Studi Kasus di Kelurahan Lempake Samarinda)", 13(1): $1-11$. 
T Karyani, A Susanto, E Djuwendah, and H Hapsari. 2020. Red Chili Agribusiness and the Risks Faced by the Farmers. IOP Conf. Series: Earth and Environmental Science $466 \quad$ (2020) 012002. doi:10.1088/1755-1315/466/1/012002

Kementerian Pertanian RI. 2018. Laporan Tahunan Kementan 2017. Kementerian Pertanian RI. Melalui $<$ https://www.pertanian.go.id/home $/$ ? show $=$ page\&act $=$ view $\&$ id $=18>$ [06/01/19].

Piay, Sherly Sisca., Tyasdjaja, Ariarti., Ermawati, Yuni., Hantoro, F. Rudi Prasetyo. 2010. Budidaya dan Pascapanen Cabai Merah (Capsicum annuumL.) Badan Penelitian dan Pengembangan Pertanian Balai Pengkajian Teknologi Pertanian Jawa Tengah Ungaran.

Pusat Penyuluh Pertanian. 2019. Data kelompok Tani Provinsi Jawa Barat Kabupaten Garut, Sistem Informasi Management Penyuluh Pertanian. Melalui

$<$ https://app2.pertanian.go.id/simlu $\underline{\text { h2014 }}>$ [05/01/19].

Prajnata, Final. 2011. Mengatasi Permasalahan Bertanam Cabai. Jakarta: Penebar Swadaya.

Ridiyanto, Taufik., Soetoro dan Tito H. 2017. Analisis Usahatani Cabai Merah (Capsicum annum L.) Varietas Hot Beauty. Jurnal Ilmiah Mahasiswa Agroinfo Galuh, 4(2): 132-139.

Sastraatmaja, Entang. 2010. Suara Petani. Bandung: Masyarakat Geografi Indonesia.

Soekartawi. 2016. Analisis Usahatani. Jakarta: UI Press.

Stefina Liana Sari, Rija Sudirja dan Emma Trinurani Sofyan. 2017. Aplikasi PCO Plus pada Tanah Bekas Tambang Batu
Bata Merah terhadap Serapan P, Ca dan B serta Fruitset Cabai Merah Besar (Capsicum annuum L.). Jurnal Agrikultura 2017, 28 (2): 68-73.

Suratiyah K. 2015. Ilmu Usahatani Edisi Revisi. Jakarta: Swadaya.

Syamsiyah, Nur., Thoriq, Ahmad., Pardian, Pandi., Karyani, Tuti., Kusno, Kuswarini. 2017. Tingkat Pendapatan Usahatani Padi dan Kontribusinya terhadap Pendapatan Petani. Jurnal Agribisnis Terpadu, 10(1): 76-88. 